\title{
Perianal Allergic Contact Dermatitis from Benzocaine - a Case Report
}

\author{
Malena GERGOVSKA ${ }^{1}$, Kristina SEMKOVA ${ }^{1}$, Jana KAZANDJIEVA ${ }^{1}$, Nikolay TSANKOV $^{2}$ \\ ${ }^{1}$ Department of Dermatology and Venereology, Medical Faculty, Medical University - Sofia, Bulgaria \\ ${ }^{2}$ Clinic of Dermatology and Venereology, Tokuda Hospital Sofia, Bulgaria \\ *Correspondence: Jana Kazandjieva, Email: janaderm@abv.bg \\ DE GRUYTER \\ UDC 616.35-031.63-002:615.211
}

\begin{abstract}
A large number of contact allergic reactions to benzocaine have been reported since its introduction to the pharmaceutical market as an active ingredient in different over-the-counter anesthetic ointments. Benzocaine is used as a key ingredient in many pharmaceuticals, such as products for oral ulcers, wound and burn preparations, sunburn remedies, hemorrhoidal preparations, oral and gingival products, sore throat sprays/lozenges, callous and wart remedies, creams for treatment of poison ivy dermatitis, tooth ache and denture irritation products.

We present a 56-year-old Caucasian male with chronic rash, accompanied by intense itching in the perianal area. The lesions occurred two months earlier and the patient was treated with a wide range of topical antifungals, antibiotics and corticosteroids, with temporary improvement. The skin lesions were consistent with chronic allergic contact dermatitis. The patient denied using any topical preparations other than those prescribed by his dermatologist. Patch testing with the European baseline series was performed. A strongly positive reaction to benzocaine was identified on reading days 2 and 3 . Targeted history showed intermittent use of benzocaine anti-hemorrhoidal cream to treat concomitant hemorrhoids.

Benzocaine was discontinued and treatment with methylprednisolone aceponate $0.1 \%$ was initiated, resulting in significant improvement. No relapse was observed at 3-month follow-up.

In conclusion, patients with confirmed benzocaine allergy should pay special attention to product labels and avoid products that contain benzocaine and its related substances. All products labelled as "anaesthetic" or "caine" should be suspected of containing benzocaine or related compounds. Patient education and awareness are critical to avoid further episodes and relapses.
\end{abstract}

\section{Key words}

Benzocaine + adverse effects; Dermatitis, Allergic Contact; Anesthetics, Local; Pruritus Ani

$\mathrm{B}$ enzocaine is a local anesthetic, commonly used as a topical pain reliever (1). Local anesthetics are widely used in clinical practice and adverse effects are not uncommon. A large number of contact allergic reactions to benzocaine have been reported since its introduction to the pharmaceutical market as an active ingredient in different over-the-counter anesthetic ointments. Benzocaine is used as a key ingredient in many pharmaceuticals, such as products for oral ulcers, wound and burn preparations, sunburn remedies, hemorrhoidal preparations, oral and gingival products, sore throat sprays/lozenges, callous and wart remedies, creams for treatment of poison ivy dermatitis, tooth ache and denture irritation products (2).

\section{Case report}

A 56-year-old Caucasian male presented with chronic rash, accompanied by intense itching in the perianal region. The lesions occurred two months earlier and the patient was treated with a wide range of topical antifungals, antibiotics and corticosteroid with temporary improvement. Physical examination 


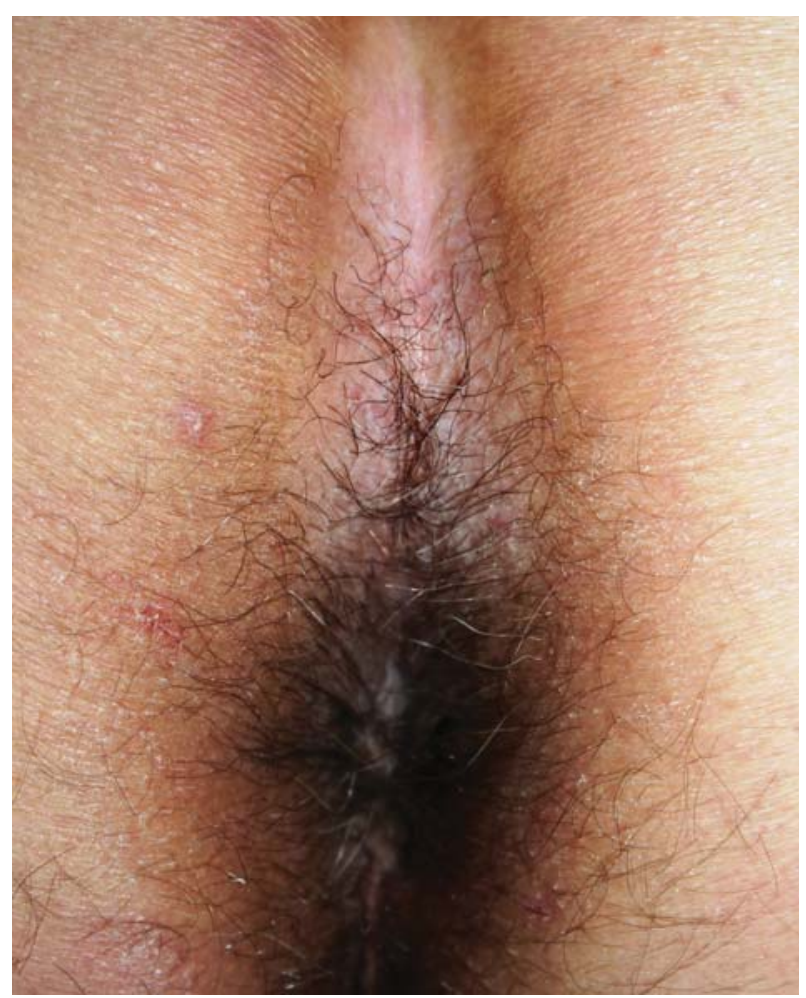

Figure 1. Perianal erythema, mild lichenification of the skin and small erythematous firm papules spread in the anogenital region revealed perianal erythema, mild lichenification of the skin and small erythematous firm papules spread in the anogenital region (Figure 1). The skin lesions were consistent with chronic allergic contact dermatitis. The patient denied using any topical preparations other than those prescribed by his dermatologist. Routine laboratory findings were within normal ranges. Bacterial and fungal tests were negative. Patch testing with the European baseline series (Chemotechnique Diagnostics, Vellinge, Sweden) was performed. The allergens were placed on the skin of the upper back for 48 hours (day 2). A strongly positive reaction to benzocaine with vesicles and erythema was identified on readings days 2 and 3 (Figure 2). Targeted history showed intermittent use of benzocaine antihemorrhoidal cream to manage his concomitant hemorrhoids.

Benzocaine was discontinued and treatment with methylprednisolone aceponate $0.1 \%$ was initiated resulting in significant improvement. No relapse was observed at 3-month follow-up.

\section{Discussion}

Benzocaine was first synthesized in 1890 by the German chemist Eduard Ritsert (1859-1946) (3) and

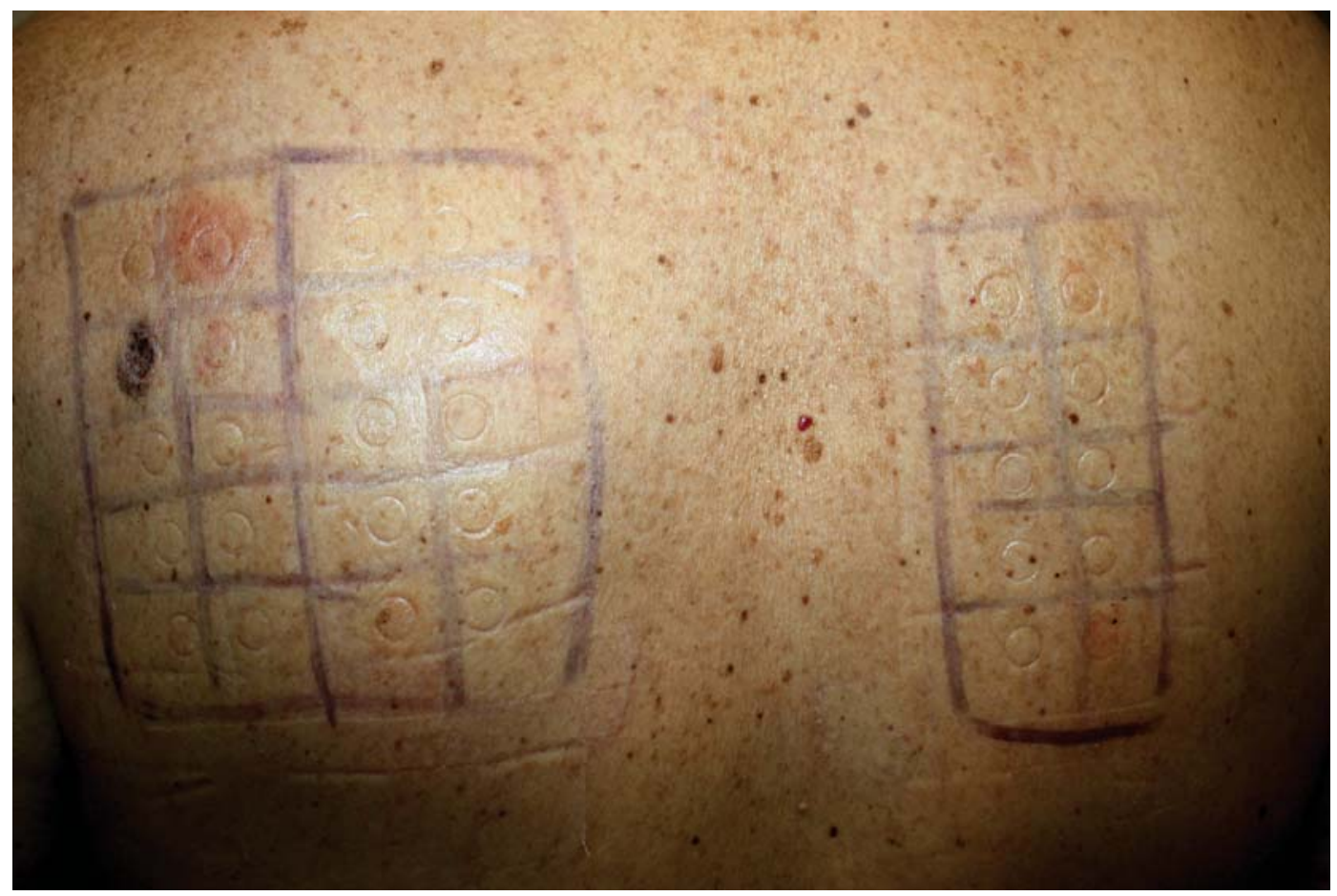

Figure 2. A strongly positive reaction to benzocaine with vesicles and erythema identified at reading on D2 and D3 
introduced to the market in 1902 under the name "Anästhesin", according to Auterhoff (4) and Demare and Regla (5). It is also known under several other names: ethyl aminobenzoate, ethyl 4-aminobenzoate, 4-aminobenzoic acid ethyl ester, and p-aminobenzoic acid ethyl ester.

Benzocaine is a topical anesthetic, an ethyl ester of p-aminobenzoic acid (PABA). Benzocaine acts to inhibit the voltage-dependant sodium channels (VDSCs) on the nerve membrane, stopping the propagation of the action potential and blocking the local nerve impulses. It is absorbed in very small quantities by the membrane and is hydrolyzed by plasma pseudocholinesterases to metabolites containing PABA, which is highly allergenic and responsible for anaphylactic reactions (5).

Benzocaine is used in many pharmaceutical preparations and rarely in cosmetics. It is also found in antihemorrhoidal creams, some oral suspensions, and cough tablets and can be applied topically to the oral mucosa during dental procedures before injecting the local anesthetic.

Allergic reactions to local anesthetics are frequent. Amide anesthetics (eg., mepivacaine, bupivacaine, lidocaine, and prilocaine) are better tolerated, whereas ester anesthetics (eg., benzocaine, procaine, tetracaine, and chloroprocaine) are more allergenic. Benzocaine yields the greatest number of positive patch test reactions in patients with allergy to ester anesthetics who tolerate amide anesthetics (6). Regarding amide and ester anestethics, the reactivity, if positive to both (amide and ester), is more likely the result of concomitant sensitization than crossreaction between them $(7,8)$. Benzocaine can crossreact with other benzoic acid-derived local anesthetics (both topical and injectable forms), as well as parabens. Parabens are alkyl ester derivatives of parahydroxybenzoic acid and are the most commonly used preservatives in the cosmetic industry. Cross-reactions with para-amino compounds, namely, benzocaine and para-phenylenediamine (PPD), have been reported but are thought to be extremely rare (8).

Paraphenylendiamine (PPD) is found in permanent hair dyes, sulfonamides, sulfonylureas, PABA-based suncreens, and thiazide-related diuretics. Possible explanations for cross-reactions include the presence of common antigenic determinants or transformation to chemically related metabolites in the skin. Benzocaine, parabens, PPD, 2,5-diaminotoluene sulfate, 2-nitro 1,4-PPD, and the azo dyes used in textiles belong to the same group. They have in common the presence of an amino substituent at the para-position of the benzene ring. This structural similarity may explain the frequency of cross-reactions (9).

Adverse effects of topical anesthetics, such as benzocaine, are various and frequent and they can be of immediate-type or delayed. Topical products containing anesthetics are increasingly applied and have the potential to cause allergic contact dermatitis. Skin patch testing for allergy should always be considered in recalcitrant cases and in cases with suspected allergic induction (10). It is estimated that $5 \%$ of patients who use topical benzocaine preparations may become sensitized to it and, thus, long-term use can result in increased incidence of hypersensitivity reactions ( $<1 \%$ of all adverse reactions) (11). Most of these reactions are $\mathrm{T}$ cell-mediated type IV delayed hypersensitivity reactions, including allergic contact dermatitis confirmed by skin patch tests. Other types of hypersensitivity reactions (type I) IgE-mediated immediate-type reactions (urticaria, angioedema, or anaphylaxis) are very rare (12).

\section{Conclusion}

Patients with confirmed benzocaine allergy should pay special attention to product labels and avoid products that contain benzocaine and its related substances. All products labelled as "anaesthetic" or "caine" should be suspected of containing benzocaine or related compounds. Patient education and awareness are critical for avoiding further episodes and relapses.

\section{Abbreviations}

PABA - para-aminobenzoic acid

VDSCs - voltage-dependant sodium channels PPD - paraphenylendiamine

\section{References}

1. Schwarz HD. Ritsert, Eduard. In: Neue Deutsche Biographie 2003. p. 653-4. [cited 2014 Jan 15]. Available from: www. deutsche-biographie.de/pnd139207848.html

2. Auterhoff H. Lehrbuch der pharmazeutischen hemie. Stuttgart: Wissenschaftliche Verlagsgesellschaft; 1968.

3. Ritsert E. Über den Werdegang des Anästhesins [On the development of anästhesin]. Pharm Ztg 1925;60:1006-8. 
4. Auterhoff H. Lehrbuch der pharmazeutischen chemie. Stuttgart: Wissenschaftliche Verlagsgesellschaft; 1980.

5. Demare P, Regla I. Synthesis of two local anesthetics from toluene: an organic multistep synthesis in a Project-Oriented Laboratory Course. J Chem Educ 2012;89:147.

6. Warshaw EM, Schram SE, Belsito DV, DeLeo VA, Fowler JF Jr, Maibach HI, et al. Patch-test reactions to topical anesthetics: retrospective analysis of cross-sectional data, 2001 to 2004. Dermatitis 2008;19:81-5.

7. Jovanovic M, Karadaglic D, Brkic S. Contact urticaria and allergic contact dermatitis to lidocaine in a patient sensitive to benzocaine and propolis. Contact Dermatitis. 2006;54:124-6.

8. Turchin I, Moreau L, Warshaw E, Sasseville D. Cross-reactions among parabens, para-phenylenediamine, and benzocaine: a retrospective analysis of patch testing. Dermatitis 2006;17(4):192-5.

9. Vu AT, Lockey RF. Benzocaine anaphylaxis. J Allergy Clin Immunol 2006;118: 534-5.

10. Finucane BT. Allergies to local anesthetics: the real truth. Can J Anaesth 2003;50:869-74.

11. Melamed J, Beaucher WN. Delayed-type hypersensitivity (type IV) reactions in dental anesthesia. Allergy Asthma Proc 2007;28:477-9.

12. Thyssen JP, Menné T, Elberling J, Plaschke P, Johansen JD. Hypersensitivity to local anaesthetics - update and proposal of evaluation algorithm. Contact Dermatitis 2008;59:69-78.

\section{Perianalni alergijski kontaktni dermatitis izazvan benzokainom - prikaz slučaja}

\section{Sažetak}

Uvod. U svetskoj stručnoj literaturi opisan je veliki broj slučajeva kontaktne senzibilizacije izazvane lokalnom upotrebom benzokaina. Ovo se može objasniti velikim brojem lokalnih farmaceutika prisutnih na farmaceutskom tržištu koji se bez lekarskog recepta mogu nabaviti, a koji u svom sastavu sadrže lokalni anestetik. Benzokain predstavlja ključnu aktivnu supstanciju u mnogim preparatima koji se koriste za lečenje oralnih ulceracija, promena na desnima, bolnih upala zuba i grla, opekotina, rana, hemoroida. Nalazi se u velikom broju preparata za ispiranje usta, ali i lokalnih pripravka za lečenje kalusa i klavusa.

Prikaz slučaja. Prikazujemo 56 godina staru pacijentkinju čija je glavna tegoba bila intenzivan svrab u perianalnom predelu. Dva meseca pre pregleda kod nas, pored osećaja svraba, na koži perianalne regije pojavilo se intenzivno crvenilo. $U$ tom vremenskom periodu, u terapiju je uvođen veći broj različitih preparata za lokalno lečenje: antimikotici, antibiotici, kortikosteroidi. Poboljšanje je bilo privremeno, tako da su u momentu pregleda promene odgovarale kliničkoj slici kontaktnog dermatitisa. Pacijentkinja je negirala upoterbu bilo kojeg lokalnog preparata osim navedenih koje joj prepisao dermatolog. Sprovedeno je alergološko testiranje epikutanim testom na kontaktne standardne alergene iz Evropske standardne serije alergena (Chemotechnique Diagnostics, Vellinge, Sweden). Utvrđen je ekcemski tip reagovanja (eritem, vezikule, otok) na benzokain. Ciljanom anamnezom otkrili smo da je pacijentkinja povremeno aplikovala na kožu obolele regije krem za lečenje hemoroida. Utvrđeno je da se u sastavu tog krema nalazio benzokain. Po prestanku upotrebe navedenog krema, uz kratkotrajnu primenu kortikosteroidnog krema (methylprednisolon aceponate $0,1 \%$ ) promene su se povukle. Na kontroli obavljenoj posle tri meseca nakon saniranja promena nije dijagnostikovan recidiv. Diskusija. Za razliku od farmaceutske industrije, kozmetički preparati retko u svom sastavu sadrže benzokain. Pored navedenog, benzokain se nalazi i u tabletama protiv kašlja, a takođe ga aplikuju u vidu spreja za vreme dentalnih procedura (ukoliko se može izbeći davanje parenteralnog lokalnog anestetika).

Neželjene reakcije (nealergijske) na sistemski primenjene lokalne anestetike su česte. Amidska grupa lokalnih anestetika (npr. mepivakain, mupivakin, lidokain, prilkain) bolje se podnose dok veći broj neželjenih efekata izaziva estarska grupa anestetika (npr. benzokain, prokain, tetrakain, hloroprokain). Benzokain je poznat kao kontaktni alergen koji izaziva najveći broj pozitivnih epikutanih reakcija i to kod pacijenata koji pritom ne pokazuju reaktivnost na amidske anestetike, ali ni na ostale pripadnike grupe estarskih anestetika. Benzokain može unakrsno reagovati sa drugim loklanim anesteticima koji predstavljaju derivate benzoeve kiseline (lokalni i parenteralni pripravci) i parabenima. Parabeni predstavljaju alkil-estarske derivate para- 
hidroksibenzoeve kiseline, koji se često koriste kao konzervansi u kozmetičkoj industriji. Unakrsno reagovanje parabena sa susptancijama koje u svom sastavu imaju para-amino grupu, npr. benzokainom ili para-fenilendiaminom izuzetno je retko opisano u stručnoj literaturi.

Zaključak. Sve osobe kod kojih je utvrđena preosetljivost na bezokain mogu da koriste samo one preparate koji u svom sastavu nemaju benzokain ili njemu hemijski slične supstancije. U sastavu svakog proizvoda koji u svom nazivu sadrži reč „,anestetik” ili „kain“ treba isključiti prisustvo benzokaina i njemu hemijski srodnih supstancija. Edukacija pacijenta je preduslov kako bi se izbegli recidivi neželjenih reakcija.

\section{Ključne reči}

Benzokain + neželjena dejstva; Alergijski kontaktni dermatitis; Lokalni anestetik; Analni pruritus 